\title{
EXPERIMENTAL AND THEORETICAL INVESTIGATION OF THE PRODUCTION OF HCI AND SOME METAL CHLORIDES IN MAGMATIC/HYDROTHERMAL SYSTEMS
}

ANNUAL REPORT: $1991-1992$

\section{DISCLAIMER}

This report was prepared as an account of work sponsored by an agency of the United States Government. Neither the United States Government nor any agency thereof, nor any of their employees, makes any warranty, express or implied, or assumes any legal liability or responsibility for the accuracy, completeness, or usefulness of any information, apparatus, product, or process disclosed, or represents that its use would not infringe privately owned rights. Reference herein to any specific commercial product, process, or service by trade name, trademark, manufacturer, or otherwise does not necessarily constitute or imply its endorsement, recommendation, or favoring by the United States Government or any agency thereof. The views and opinions of authors expressed herein do not necessarily state or reflect those of the United States Goverament or any agency thereof.

\section{Work Performed Under Contract DE-FG07-901D13025}

For

U. S. Department of Energy

Office of Industrial Technologies

Washington, D.C.

\section{By}

Department of Geology

University of Maryland at College Park Maryland 20742 


\section{DISCLAIMER}

This report was prepared as an account of work sponsored by an agency of the United States Government. Neither the United States Government nor any agency Thereof, nor any of their employees, makes any warranty, express or implied, or assumes any legal liability or responsibility for the accuracy, completeness, or usefulness of any information, apparatus, product, or process disclosed, or represents that its use would not infringe privately owned rights. Reference herein to any specific commercial product, process, or service by trade name, trademark, manufacturer, or otherwise does not necessarily constitute or imply its endorsement, recommendation, or favoring by the United States Government or any agency thereof. The views and opinions of authors expressed herein do not necessarily state or reflect those of the United States Government or any agency thereof. 


\section{DISCLAIMER}

Portions of this document may be illegible in electronic image products. Images are produced from the best available original document. 


\section{Behavior of Chlorine in Magmatic-Hydrothermal Systems}

\section{Annual Report: 1991-1992}

Our integrated field and laboratory investigation of the behavior of halogens $(\mathrm{Cl}$ and $\mathrm{F}$ ) and other halogen-bearing species ( $\mathrm{HCl}, \mathrm{HF})$ in shallow magmatic-hydrothermal systems is continuing. Our partitioning data is now being supplemented by a field investigation in a natural volcano-plutonic system, the Billy Lake-Rush Creek Complex, a 99 million year old fossil magmatic-geothermal system in the Ritter Range, Sierra Nevada Mountains. Preliminary petrographic analysis of this fossil system, measurements of the halogen content in apatite, and modelling, have yielded significant progress in our understanding of the behavior of halogens in shallow magmatic-hydrothermal systems.

Field Data

One season of field work was completed on the Billy Lake-Rush Creek volcano-hydrothermalplutonic complex. Detailed sample collection was performed to insure that samples were obtained which exhibit the mineralogical and textural variation within both the Billy Lake Granite and the Rush Creek Quartz-monzodiorite (Map 1). A large degree of emphasis during the field season consisted of collecting samples of aplite dikes and pegmatitic segregations that represent important links between the magmatic and hydrothermal stages in magma genesis and crystallization. In addition, samples were obtained from the surrounding volcanic rocks, which the Billy Lake Granite and Rush Creek Quartz-monzodiorite intruded, and have interacted with hydrothermally.

Detailed mapping was performed emphasizing the relationship between the quartz-monzodiorite and the surrounding volcanic rocks. A detailed study was made of apophyses of granite intruded into the volcanic rocks, making sure to note strike and dip of the granitic structures (e.g. aplite and pegmatite dikes, mineral lineations and foliations) and volcanic units, zonation within the granitic dikes, spatial relationship between the granite apophyses, and relationship of the apophyses to the quartz-monzodiorite. In addition, aplite orientation, foliation within the granite and quartz-monzodiorite, orientation of ductile 'shear' zones, and orientations of various contact features were noted in order to make a comprehensive field map. 
$\underline{\text { Results }}$

Field observations suggest that the Billy Lake-Rush Creek Complex, which was emplaced at a shallow depth in the crust, fractured only to a modest degree. This result is advantageous as it allows the hydrothermal relationships to be worked out with a low degree of ambiguity. We have documented the existence of aplitic veins which grade laterally into hydrothermal veins. These hydrothermal veins bear a minimum amount of alteration, and can be seen cutting veins with greatly different strike and dip that contain calcic minerals and possess highly altered selvages. We interpret these veins to have formed from fluids that originated external to the orthomagmatic-hydrothermal system. Where these two subplanar veins and the outcrop surface intersect, small (cm scale) zones of altered sulfide are found. This motif was observed many times in the field area.

\section{Petrography}

Petrographic analysis has been performed on thin sections from the Billy Lake-Rush Creek Complex. Special care has been taken to note size and shape of apatite, petrographic relationship of apatite to other minerals, inclusion patterns within apatite, etc., in order to elucidate the spatial and temporal relationship of apatite to other mineral phases.

Apatite is present in host rocks and aplites throughout the Billy Lake-Rush Creek Complex. Apatite is present dominantly as a subhedral phase, with minor amounts of anhedral apatite. Apatite is present as an intercumulus phase, and as inclusions in feldspars, mafics, and rarely quartz. Apatite often contains randomly oriented inclusions of phases which have not yet been identified $(<5 \mathrm{~m}$ long).

\section{Apatite Analyses}

Polished thin sections have been made and preliminary, detailed petrography is continuing to take

place. Special attention is being paid to the relationship between apatite and surrounding minerals. Microfiche mosaics are being compiled so that subsequent petrographic interpretation, and identification, can be completed with ease. Concurrently, a detailed procedure is being developed using electron probe, to analyze halogen-bearing minerals in order to obtain accurate and precise halogen analyses.

Preliminary halogen analyses within apatite have been obtained from host rocks, aplites and mafic 
enclaves within the Billy Lake-Rush Creek Complex. Apatites have been found to be unzoned within the resolution of the of the electron microprobe. Preliminary analyses also suggest that size and morphology. of apatites do not have any correlation with halogen contents of these grains.

Apatites from the quartz-monzodiorite of Rush Creek have the lowest F contents, averaging 2.98 wt.\% $\left(X_{F A_{p}}^{A}=0.791\right)$, whereas apatites from the granite of Billy Lake have higher values (3.14 wt. \%; $X_{F A P}^{A A}$ $=0.833)$. The $\mathrm{Cl}$ contents of apatites from both plutons are similar $\left(0.03 \mathrm{wt} . \%\left(\mathrm{X}_{C A_{p}}^{A}=0.004\right)-q u a r t z-\right.$ monzodiorite; 0.05 wt.\% $\mathrm{Cl}\left(\mathrm{X}_{\mathrm{C} \mathrm{A}_{\mathrm{p}}}=0.008\right)$ - granite). These values suggest that hydroxyl component of these apatites are as follows: 0.69 wt. $\%\left(X_{f A_{p}}^{A P_{p}}=0.205\right.$; quartz-monzodiorite $)$ and 0.54 wt. \% $\left(X_{\mathrm{H}}^{A R_{p}}=0.160\right.$; granite) (Table 1; Figure 1).

Apatites within aplites of the Rush Creek pluton have somewhat higher F contents (3.56 wt. \%;

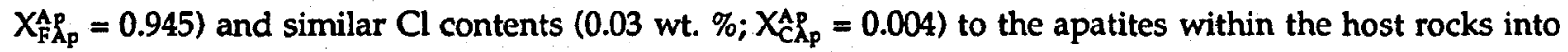
which these intrude. The calculated hydroxyl concentration of aplitic apatite is 0.09 wt. $\%\left(X_{\mathrm{HA}}^{A R_{P}}=0.051\right)$. Theoretical Models of Apatite Chemistry

Two models have been formulated which yield information about the magmatic-hydrothermal transition. First, a model has been derived which can be used to estimate the concentration of the halogens in apatite as a magma rises towards the surface (first boiling). Second, given reasonable assumptions, a model has been formulated which yields estimates of the halogen concentrations of a melt given the temperature at which apatite crystallizes, pressure, melt composition, and which exsolves an aqueous phase due to second boiling (shallow or deeply emplaced plutons).

\section{Modelling of the Halogen Concentration in Apatite During First Boiling}

A first order model has been formulated to estimate the halogen concentration in apatite that is in equilibrium with a magma that exsolves a magmatic volatile phase due to first boiling. This preliminary model can be used to evaluate apatite composition in shallow silicic melts that rise to the surface. Preliminary comparison of the results of the model to a natural system in which much geochemical data exists, Obsidian Dome which is spatially related to the Long Valley Caldera, have been made. 
Melt inclusions from Obsidian Dome have been described in detail (Hervig and others 1989; Westrich and others, 1988) and these serve as appropriate input parameters for these calculations. Apatite compositions have been simulated in this example for the Obsidian Dome magma as it rises towards the surface and exsolves an aqueous phase due to first boiling (figure 2). Input parameters for the calculation are derived from the work of Hervig and others (1989). In this study, Hervig and others suggest that melt inclusions can be used to obtain estimates of pre-eruptive melt composition. Hervig and others analyzed melt inclusions in a variety of phenocrysts from Obsidian Dome for $\mathrm{F}, \mathrm{Cl}$ and $\mathrm{H}_{2} \mathrm{O}$; Obsidian Dome was estimated to contain $600 \mathrm{ppm} \mathrm{Cl}, 340 \mathrm{ppm} \mathrm{F}$, and 4.1 wt.\% water, prior to eruption. These are somewhat lower than the values of $800 \mathrm{ppm} \mathrm{Cl}$ and $500 \mathrm{ppm} \mathrm{F}$ reported by Westrich and others (1988) but there is a wide range of values reported in both studies. Pressure ranges from 1 to $0 \mathrm{kbar}$ (corresponding to $C_{\mathrm{H} 20}^{1, s}$ of 0.042 to 0.00 ). On the $y$-axis is the calculated mole fraction of the apatite end members: $X_{C A_{p}}^{A}, X_{F}^{A} R_{p}$, and $X_{A}^{A R_{p}} X_{F A p}^{A}$ increases, and $X_{A}^{A R_{p}}$ decreases monotonically as the magma approaches the surface, whereas $\mathrm{X}_{C X_{\mathrm{p}}}^{A}$ remains approximately constant. $\mathrm{X}_{F R_{p}}$ approaches 1 and by convention, $X_{\mathrm{H}}^{A R_{p}}$ goes to 0 as the melt reaches the surface.

The ratio of $X_{C A_{p}}^{A} / X_{F R_{p}}^{A}$ remains approximately constant as the magma rises to the surface because both $X_{C A_{p}}^{A}$ and $X_{F A_{p}}^{A P_{p}}$ (figure 3). Conversely, the ratio of $X_{C A_{p}}^{A P_{p}} / X_{F A_{p}}^{A P_{p}}$ decreases initially, then increases rapidly, as the solubility of water in the melt trends to 0 as the magma reaches the surface. If a magma

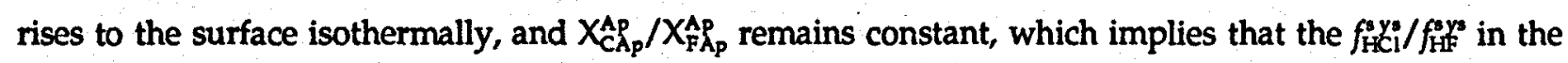
system remains constant (neglecting the pressure correction). On the other hand, a rise in $X_{C A_{p}}^{A} / X_{H A P}^{A P}$ suggests an increase in $f_{\mathrm{H}_{1}}^{3 y^{3}} / f_{\mathrm{H}^{\circ} \mathrm{O}^{\circ}}$. This trend in expected due to more rapid rate of decrease of water than $\mathrm{Cl}$ in the melt.

The results of this preliminary modelling appear promising (see Piccoli, 1992). It is the hope that the model when complete, will yield insight into shallowly emplaced felsic magmas, and the magmatichydrothermal transition. This modelling yields insight into the $\mathrm{Cl}$ concentrations in apatite which are higher than expected in plutonic rocks which are emplaced to shallow levels, e.g. apophyses of the Bingham porphyry deposit (Piccoli, 1992). 


\section{Model to Estimate the Initial Halogen Concentrations of Silicic Plutonic Rocks}

Variations in the concentration of the halogens in apatite can be used to deduce changes in fugacity ratios during the crystallization of granitoids. In addition, a model initial concentration of $\mathrm{Cl}$ and F in the melt and the associated magmatic volatile phase (MVP) can be calculated if the temperature of apatite crystallization and the activity of the $\mathrm{H}(\mathrm{Na})_{-1}$ component in the system can be approximated. Model apatite saturation temperatures (AST) can be calculated given appropriate apatite solubility data in silicate melts, by assuming that the initial melt composition is equal to the whole rock composition and that apatite has crystallized from the melt.

The model presented here (which is described in detail in Piccoli, 1992, and Piccoli and Candela, submitted) can be used to estimate the initial halogen content of metaluminous, felsic magmas. The model is designed to simulate a magma which exsolves a magmatic volatile phase due to crystallization at a constant pressure (second boiling).

Estimations of apatite crystallization temperature can be gathered by comparing natural and experimental systems. Harrison and Watson (1984) found that for metaluminous melts with $\mathrm{C}_{\mathrm{SiO} 2}^{\text {l,o }}$ of $45-75 \%, C_{H-20}^{1}$ of $0-10 \%$, and at pressures exhibited in the crust, the solubility of apatite could be expressed as a function of temperature, and the instantaneous $\mathrm{C}_{S 102}^{1}$ and $\mathrm{C}_{\mathrm{P2} O 5}^{1}$ at which the apatite crystallizes. The effects of water concentration, pressure, and the concentration of calcium on apatite solubility were not significant independent controls on apatite solubility within the rather narrow confines of the basalt-daciterhyolite temperature-composition space and the limits of precision of their experiments. The experiments of Harrison and Watson (1984) have been recast as an empirical solubility expression, and solved for temperature their results can be represented as

$$
T=\frac{\left[26,400 \cdot C_{\mathrm{SOO}_{2}}^{l}-4,800\right]}{\left[12.4-C_{\mathrm{SOO}_{2}}^{l}-\ln \left(C_{\mathrm{P}_{2} \mathrm{O}_{3}}^{l}\right)-3.97\right]}
$$

where $\mathrm{T}$ is the apatite saturation temperature (in kelvins), and $\mathrm{C}_{\mathrm{SOO} 2}^{\mathrm{a}}$ and $\mathrm{C}_{\mathrm{P} 205}^{\mathrm{r}}$ represent the concentration of phosphorus and silica in the melt at the temperature at which apatite begins to crystallize (C $\mathrm{C}_{\mathrm{SiO2}}^{\mathrm{AST}}$ and $\mathrm{C}_{\mathrm{P} 205}^{1, A S T}$ are expressed as weight fractions [wt.\% / 100]). Generally these values will not be the whole rock 
concentrations $\left(\mathrm{C}_{\mathrm{S} 10_{2}}^{\mathrm{t}, \mathrm{O}}\right.$ and $\left.\mathrm{C}_{\mathrm{P} 2 \mathrm{O}_{5}}^{1,0}\right)$, except in those cases where apatite is a liquidus or near-liquidus phase. If apatite is the liquidus phase, the calculation of the temperature at which apatite begins to crystallize is straightforward given whole rock phosphorus and silica as estimators of $\mathrm{C}_{\mathrm{S} \text { SO2 }}^{1, \mathrm{AST}}$ and $\mathrm{C}_{\mathrm{P} 2 \mathrm{O} 25}^{1}$. Whereas this is not an unusual case in felsic melts, it is not true universally. The solubility of apatite is higher in more mafic magmas (e.g. Rush Creek Quartz-monzodiorite) and apatite may not appear until $1 / 3$ of the melt has crystallized. Therefore, before a model AST can be calculated for most intermediate to mafic melt compositions, the instantaneous concentration of $\mathrm{P}_{2} \mathrm{O}_{5}$ and $\mathrm{SiO}_{2}$ as a function of progressive crystallization upon cooling must be estimated (for an explanation of how this is accomplished, see Piccoli, 1992, or Piccoli and Candela, submitted).

Once an estimate of the temperature of apatite crystallization is obtained, it can be used to make estimates of $\mathrm{Cl}$ and $\mathrm{F}$ concentrations in the melt and aqueous phase. As described in Piccoli and Candela (submitted) and Piccoli (1992), a series of equations can be derived which relate the $\mathrm{Cl}$ and $\mathrm{F}$ concentration in apatite to aqueous phase and melt $\mathrm{Cl}$ and $\mathrm{F}$ (for metaluminous melts);

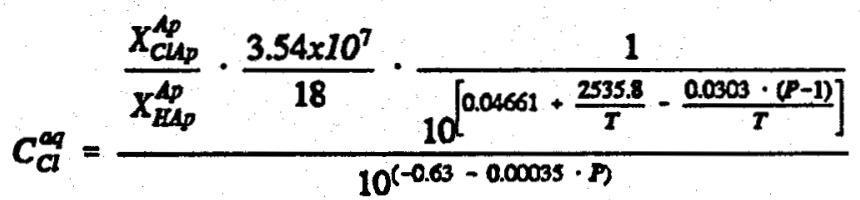

$$
\begin{aligned}
& C_{C l}^{l}=\frac{\frac{X_{C L p}^{\Delta p}}{X_{H L p}^{A p}} \cdot \frac{3.54 \times 10^{7}}{18} \cdot \frac{1}{10^{\left[0.04661+\frac{2535.8}{T}-\frac{0.0303 \cdot(P-1)}{T}\right]}}}{D_{C l}^{\alpha Q / l} \cdot 10^{(-0.63-0.00035 \cdot P))}} \\
& C_{F}^{\infty q}=\frac{X_{F A p}^{A p}}{X_{R L p}^{A p}} \cdot \frac{1.90 \times 10^{7}}{18} \cdot \frac{1}{10^{\left[0.18219+\frac{5301.1}{T}-\frac{0.00360 \cdot(P-1)}{T}\right]}} \\
& C_{F}^{\prime}=\frac{\frac{X_{F A p}^{A p}}{X_{E L p}^{A p}} \cdot \frac{1.90 \times 10^{7}}{18} \cdot \frac{1}{\left.10^{[0.18219}+\frac{3301.1}{T}-\frac{0.00360 \cdot(P-1)}{T}\right]}}{D_{F}^{\alpha q / l}}
\end{aligned}
$$


where $X_{C A p}^{A} X_{F}^{A} X_{p}$ and $X_{H A_{p}}^{A P_{p}}$ are the mole fraction of chlor-, fluor- and hydroxyapatite in apatite, $D_{C}^{a q / 1}$ and $D_{F}^{a g / l}$ are the Nernst Partition coefficients for $\mathrm{Cl}$ and $\mathrm{F}$ between magmatic volatile phase and melt, $\mathrm{P}$ is the pressure in bars, $\mathrm{T}$ is absolute temperature, $C_{C I}^{a g}$ and $C_{F}^{a g}$ are the concentrations of $\mathrm{Cl}$ and $\mathrm{F}$ in the aqueous phase, and $\mathrm{C}_{\mathrm{C}}^{1}$ and $\mathrm{C}_{\mathrm{F}}^{1}$ are the estimated melt $\mathrm{Cl}$ and $\mathrm{F}$ concentrations.

\section{Application to Billy Lake-Rush Creek Complex}

Published whole rock $\mathrm{SiO}_{2}$ and $\mathrm{P}_{2} \mathrm{O}_{5}$ from Kistler and Swanson (1981) have been used to make estimates of the temperature at which apatite begins to crystallize in the Billy Lake-Rush Creek Complex (Table 2). The 'average' composition of the quartz-monzodiorite of Rush Creek and the granite of Billy Lake yield similar estimates $\left(908^{\circ} \mathrm{C}\right)$ assuming crystallization is minimal (values for the quartzmonzodiorite of Rush Creek vary from $854-931^{\circ} \mathrm{C}$; granite of Billy Lake $893-934^{\circ} \mathrm{C}$ ) (individual results of calculations are in Table 2). The similarity in estimated AST's between Billy Lake Granite and Rush Creek Quartz-monzodiorite appears perplexing at first glace; although the $\mathrm{SiO}_{2}$ is lower in the Rush Creek pluton, the $\mathrm{P}_{2} \mathrm{O}_{5}$ is elevated, relative to the Billy Lake pluton.

The solubility expression can be modified to incorporate crystallization in silicic systems and migration of silica composition as felsic systems mature. When these parameters are incorporated into the Billy Lake-Rush Creek calculations, these preliminary estimates suggest that the AST for the quartzmonzodiorite is $957^{\circ} \mathrm{C}$ and apatite begins to crystallize after approximately $33 \%$ crystallization. Similarly, for the granite, the estimated AST is slightly lower, approximately $947^{\circ} \mathrm{C}$, however the magma has crystallized only $8 \%$ prior to the crystallization of apatite. Further, calculations suggest an AST of $820^{\circ} \mathrm{C}$ for apatites within aplite dikes in the granite, well below the AST of their respective host rocks.

These estimates of the temperatures at which apatite begins to crystallize and the measured halogen contents within apatite can be used in conjunction with the thermodynamic data to yield estimates of fugacities of hydrogen-halides and subsequently magmatic volatile phase and melt $\mathrm{Cl}$ and F. Given the composition of the quartz-monzodiorite apatites listed above, calculations suggest that the melt contained approximately $250 \mathrm{ppm} \mathrm{Cl}$ and $700 \mathrm{ppm} \mathrm{F}$ at the AST (i.e. after the melt had crystallized $33 \%)$. Assuming incompatibility of the halogens prior to reaching the AST, estimates of initial halogen 
concentrations can be obtained: $C_{C i}^{1,0}=190 \mathrm{ppm}$ and $C_{F}^{1,0}=525 \mathrm{ppm}$. However, these calculations are only preliminary, and will be superseded by further reports.

In the calculations above, we have assumed that all apatites are magmatic. The presence of chlorite and altered plagioclase within the granite and quartz-monzodiorite suggests that alteration may play a role in leading to erroneous estimates of initial melt $\mathrm{Cl}$ and $\mathrm{F}$ for 2 reasons: 1) the apatites may in fact not be magmatic in origin, but are hydrothermal, and 2) the halogen signature of magmatic apatite may be changed due to subsolidus exchange with a hydrothermal fluid. We are currently endeavoring to develop criteria for determining whether apatite composition represents earlier or later stages of magmatic-hydrothermal development. 
Table 1: Apatite Analyses

\begin{tabular}{|c|c|c|c|c|c|}
\hline & \multicolumn{3}{|c|}{$\begin{array}{c}\text { Billy Lake } \\
\text { Granite }\end{array}$} & \multicolumn{2}{|c|}{$\begin{array}{c}\text { Rush Creek } \\
\text { Quartz-monzodiorite }\end{array}$} \\
\hline . & $\begin{array}{l}\text { Host } \\
\text { Rock }\end{array}$ & Aplites & $\begin{array}{l}\text { Mafic } \\
\text { Enclaves }\end{array}$ & Host Rock & Aplites \\
\hline Number & 5 & 3 & 2 & 10 & 2 \\
\hline $\mathrm{CaO}$ & 54.97 & 54.42 & 53.93 & 54.64 & 53.88 \\
\hline $\mathrm{P}_{2} \mathrm{O}_{5}$ & 40.82 & 40.74 & 39.46 & 41.66 & 36.85 \\
\hline F & 3.14 & 3.26 & 3.65 & 2.98 & 3.56 \\
\hline $\mathrm{Cl}$ & 0.05 & 0.05 & 0.03 & 0.03 & 0.03 \\
\hline $\mathrm{OH}(\mathrm{c})$ & 0.54 & 0.43 & 0.09 & 0.69 & 0.18 \\
\hline$-\mathrm{O}=\mathrm{F}+\mathrm{Cl}$ & 1.33 & 1.39 & 1.54 & 1.26 & 1.67 \\
\hline Total & 98.19 & 97.52 & 95.61 & 98.73 & 92.86 \\
\hline$X_{F}^{A} p_{p}$ & 0.833 & 0.866 & 0.970 & 0.791 & 0.945 \\
\hline$X_{C A p}^{A P}$ & 0.008 & 0.007 & 0.004 & 0.004 & 0.004 \\
\hline$X_{H_{A}}^{A P}$ & 0.160 & 0.126 & 0.026 & 0.205 & 0.051 \\
\hline$X_{F}^{A P_{p}} / X_{H}^{A R_{p}}$ & 6.785 & 7.625 & 13.682 & 2.142 & 18.529 \\
\hline $\mathrm{X}_{\mathrm{C} \mathrm{A}_{\mathrm{p}}}^{\mathrm{A}_{\mathrm{p}}} / \mathrm{X}_{\mathrm{A} \mathrm{A}_{\mathrm{p}}}^{\mathrm{A}}$ & 0.063 & 0.064 & 0.093 & 0.021 & 0.078 \\
\hline
\end{tabular}

Number represents the number of grains analyzed, each of which contained 2-5 analyses. $X_{F A p}^{A} X_{C A p}^{A}$ and $\mathrm{X}_{\mathrm{H} \mathrm{AP}_{\mathrm{P}}}$ are the mole fractions of fluor-, chlor- and hydroxyapatite in apatite, respectively. 
Table 2: Apatite Saturation Calculations

\begin{tabular}{|c|c|c|c|c|c|c|c|}
\hline \multirow[b]{2}{*}{ Sample \# } & \multicolumn{3}{|c|}{$\begin{array}{l}\text { Quartz-monzonite of Rush } \\
\text { Creek }\end{array}$} & \multicolumn{3}{|c|}{ Granite of Billy Lake } & \multirow{2}{*}{\begin{tabular}{|l} 
Aplite \\
MC-14B
\end{tabular}} \\
\hline & Sr-13 & MC-29 & Sr-22 & Sr-12 & MC-14A & Sr-10 & \\
\hline $\mathrm{C}_{\mathrm{Si02}}^{1,0}$ & 60.0 & 63.37 & 64.5 & 68.1 & 68.99 & 69.0 & 76.12 \\
\hline $\mathrm{C}_{\text {Pzios }}^{1, i 0}$ & 0.25 & 0.18 & 0.22 & 0.16 & 0.10 & 0.12 & 0.02 \\
\hline AST (unc) & 854 & 895 & 931 & 934 & 893 & 913 & 820 \\
\hline AST (cor) & 968 & 954 & 963 & 959 & 934 & 950 & 820 \\
\hline$C_{\text {SiO2 }}^{1, A T}$ & 65.4 & 64.3 & 66.4 & 69.6 & 72.1 & 71.8 & 76.14 \\
\hline$C_{\text {PíOS }}^{1, A T}$ & 0.274 & 0.275 & 0.31 & 0.174 & 0.109 & 0.131 & 0.021 \\
\hline Crystallinity & 23 & 35 & 30 & 8 & 9 & 8 & $<5$ \\
\hline
\end{tabular}

Number represents the number of grains, each of which contained 2-5 analyses. Whole rock analyses are from Kistler and Swanson (1981). AST(cor) and AST(unc) are the calculated apatite saturation temperatures which are both uncorrected and corrected for crystallization of aluminosilicates, respectively, prior to apatite crystallization. $\mathrm{C}_{\text {SiO2 }}^{1,0}$ and $\mathrm{C}_{\text {P2OS }}^{1,0}$ are the initial $\mathrm{SiO}_{2}$ and $\mathrm{P}_{2} \mathrm{O}_{5}$ in the melt. $\mathrm{C}_{\text {SiO2 }}^{1, A S T}$ and $\mathrm{C}_{\mathrm{P} 205}^{1, A S T}$ are the concentration of $\mathrm{SiO}_{2}$ and $\mathrm{P}_{2} \mathrm{O}_{5}$ in the melt at the point where apatite becomes saturated. Crystallinity is the crystallinity of the melt when apatite becomes saturated assuming that $\mathrm{P}_{2} \mathrm{O}_{3}$ behaves incompatibly. 


\section{References}

Hanson, R.B., Sorenson, S.S., Barton, M.D., and Fiske, R.S., (accepted for publication) Long-Term Evolution of Fluid-Rock Interactions in Magmatic Arcs: Evidence from the Ritter Range Pendant, Sierra Nevada, California, and Numerical Modeling. Journal of Petrology.

Harrison, T.M. and Watson, E.W. (1984) The behavior of apatite during crustal anatexis: Equilibrium and kinetic considerations. Geochimica et Cosmochimica Acta, 48, 1467-1477.

Hervig, R.L., Dunbar, N., Westrich, H.R. and Kyle, P.R. (1989) Pre-eruptive water content of rhyolitic magmas as determined by ion microprobe analyses of melt inclusions in phenocrysts. Journal of Volcanology and Geothermal Research, 36, 293-302.

Kistler, R.W., and Swanson, S.E. (1981) Petrology and Geochronology of Metamorphosed Volcanic Rocks and a Middle Cretaceous Volcanic Neck in the East-Central Sierra Nevada, California. Journal of Geophysical Research, 86, 10489-10501.

Piccoli, P.M., 1992, Apatite Chemistry in Felsic Magmatic Systems. Ph.D. Dissertation, University of Maryland at College Park, 293 p.

Piccoli, P.M. and Candela, P.A., Apatite in felsic rocks: a model for the estimation of initial halogen contents in the Bishop Tuff (Long Valley) and Tuolumne Intrusive Suite (Sierra Nevada Batholith) Magmas. Submitted to the American Journal of Science.

Westrich, H.R., Stockman, H.W. and Eichelberger, J.C. (1988) Degassing of rhyolitic magma during ascent and emplacement. Journal of Geophysical Research, 93, 6503-6511. 
Map 1: Map of the Billy Lake-Rush Creek Volcano-plutonic Complex. Open squares represent sites where samples were collected during the 1991-1992 season, filled squares- samples collected by Dr. R.W. Kistler (personal communication) some of which are reported in Kistler and Swanson, 1981). The numbers on the map represent the uncorrected estimates of the temperature $\left({ }^{\circ} \mathrm{C}\right)$ at which apatite begins to crystallize in melts of the compositions reported in Kistler and Swanson (1981) using the equation described in the text. The values for the AST(unc) of 893 represents a host rock value, whereas the adjacent estimate of $820^{\circ} \mathrm{C}$ is for apatites within an aplite dike at the same locality, which may in fact represent the temperature at which the aplite was intruded into the host rock. Abbreviations are as follows: $\mathrm{Kb}$ - Granite of Billy Lake, $\mathrm{Kr}$ - Quartz-monzodiorite of Rush Creek, Qt-Till of Tioga age, Kk - Granodiorite of Kuna Crest (Tuolumne Intrusive Suite), Jw - Diorite of Waugh Lake, JhVolcanic flows and homfels, Ja- Andesite flows and breccia. Map is modified from Kistler and Swanson, 1981.

Figure 1: Plot of the ratio of chlorapatite to hydroxyapatite $\left(\mathrm{X}_{\mathrm{Cl} A \mathrm{p}}^{A \mathrm{~A}} / \mathrm{X}_{\mathrm{HAp}}^{A \mathrm{~A}_{\mathrm{p}}}\right)$ and fluorapatite to hydroxyapatite ratio

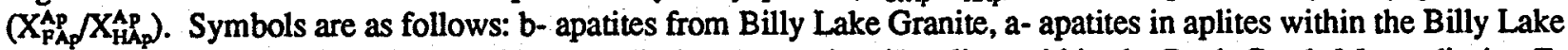
Granite, R-apatites from Rush Creek Monzodiorite, A- apatites in aplites within the Rush Creek Monzodiorite, Eapatites from mafic enclaves included within the Rush Creek Monzodiorite.

Figure 2. Plot of the calculated $X_{C A_{p}}^{A p}, X_{\mathrm{PAp}_{p}}^{A_{p}}$ and $X_{\mathrm{HAp}}^{A p}$ in equilibrium with Obsidian Dome melt as it rises towards the surface. Input parameters for the calculation are $600 \mathrm{ppm} \mathrm{Cl}$, and $340 \mathrm{ppm} \mathrm{F}$, at a pressure of $1 \mathrm{kbar}$, as suggested from the work of Hervig and others (1989).

Figure 3. Plot of the estimated $X_{C A P}^{A P} X_{H A p}^{A P}$ and $X_{C A P}^{A P} / X_{F_{A P}}^{A P}$ and measured apatite analyses from Obsidian Dome.

Figure 4. Top. Plot of the estimated $\mathrm{Cl}$ and $\mathrm{F}$ content in the Obsidian Dome melt upon rise towards the surface. Bottom. Plot of the estimated $\mathrm{Cl}$ and $\mathrm{F}$ content in the magmatic volatile phases the Obsidian Dome Magma rises towards the surface. 


\section{Billy Lake-Rush Creek Complex}

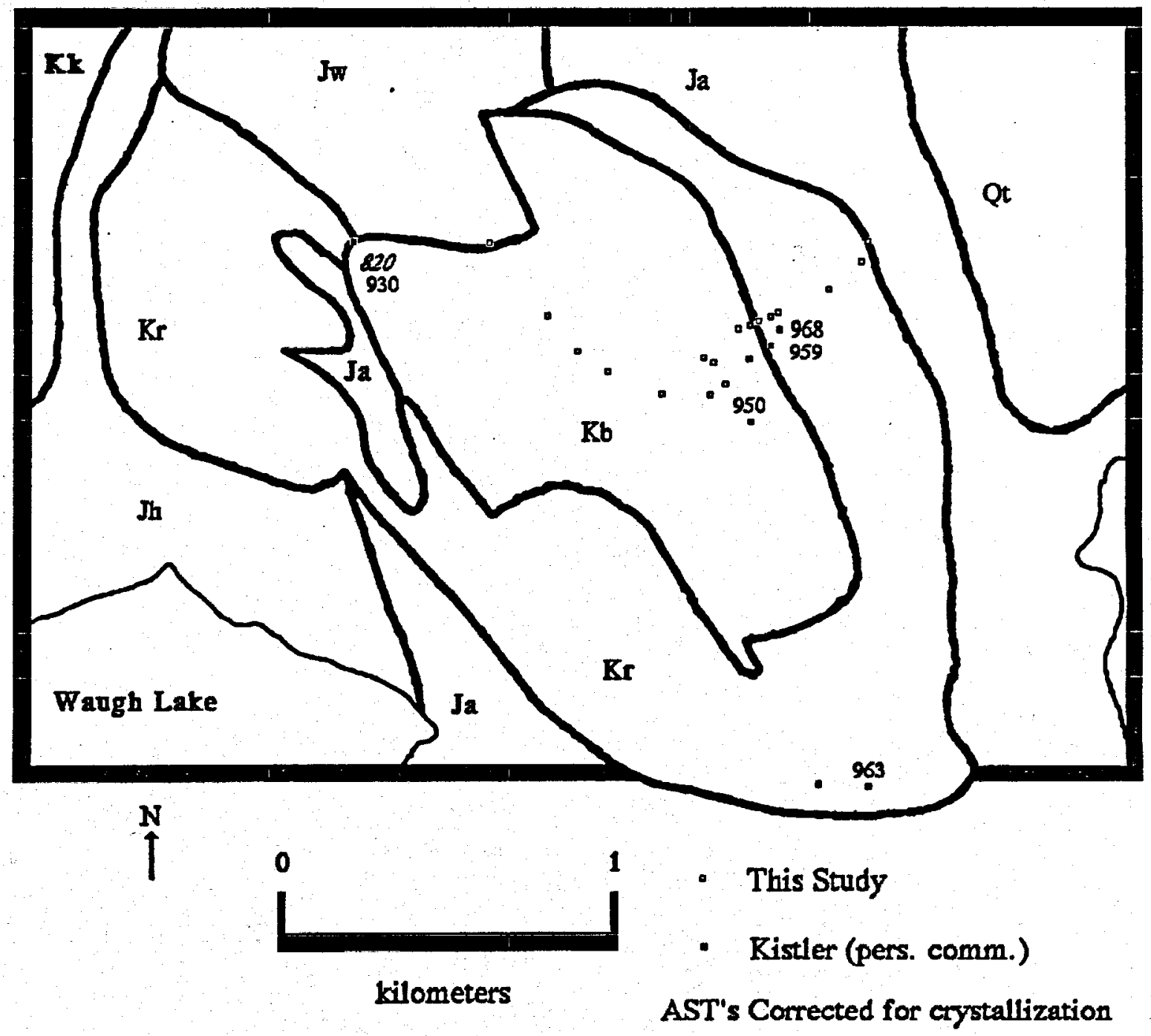




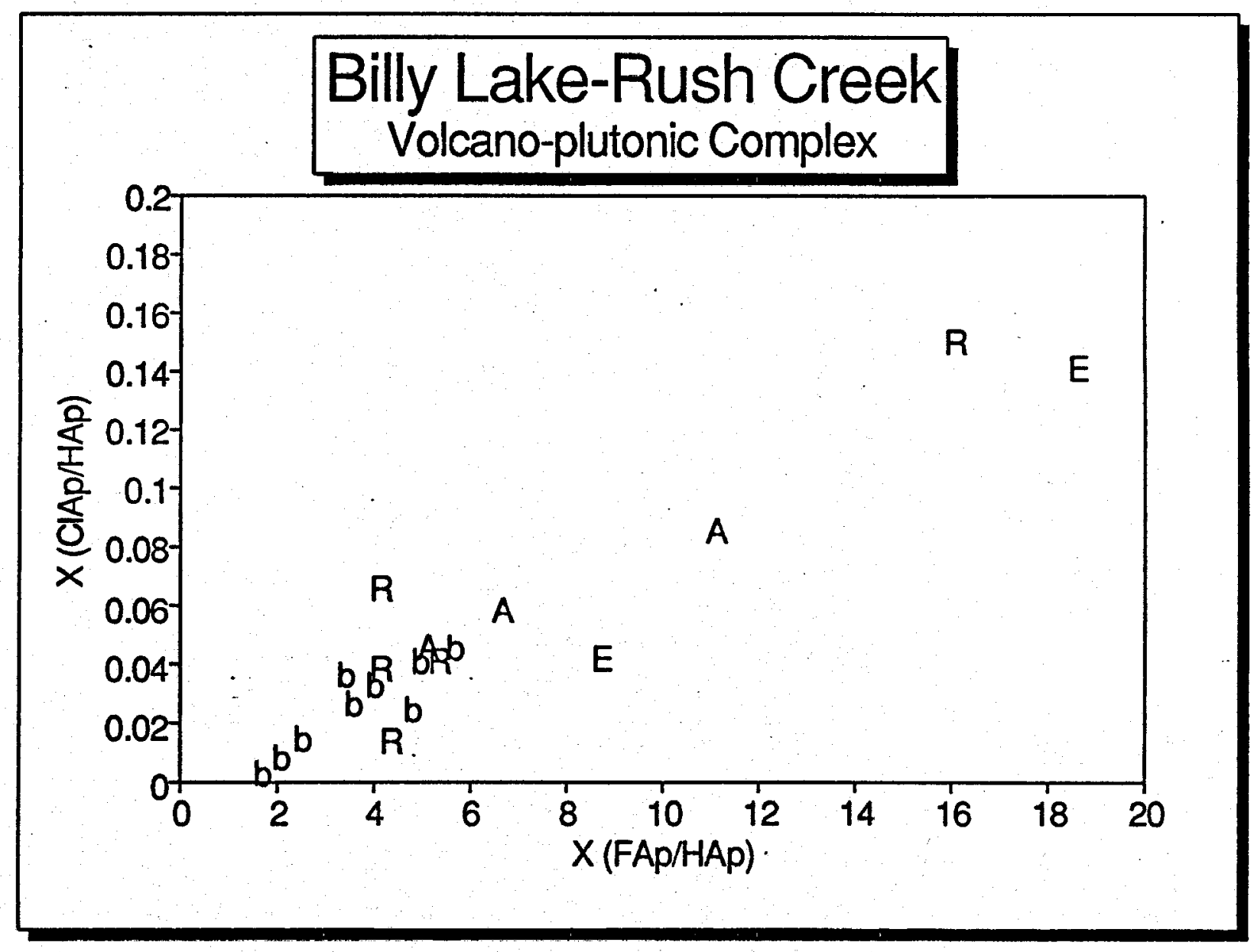

FIgURE 1 


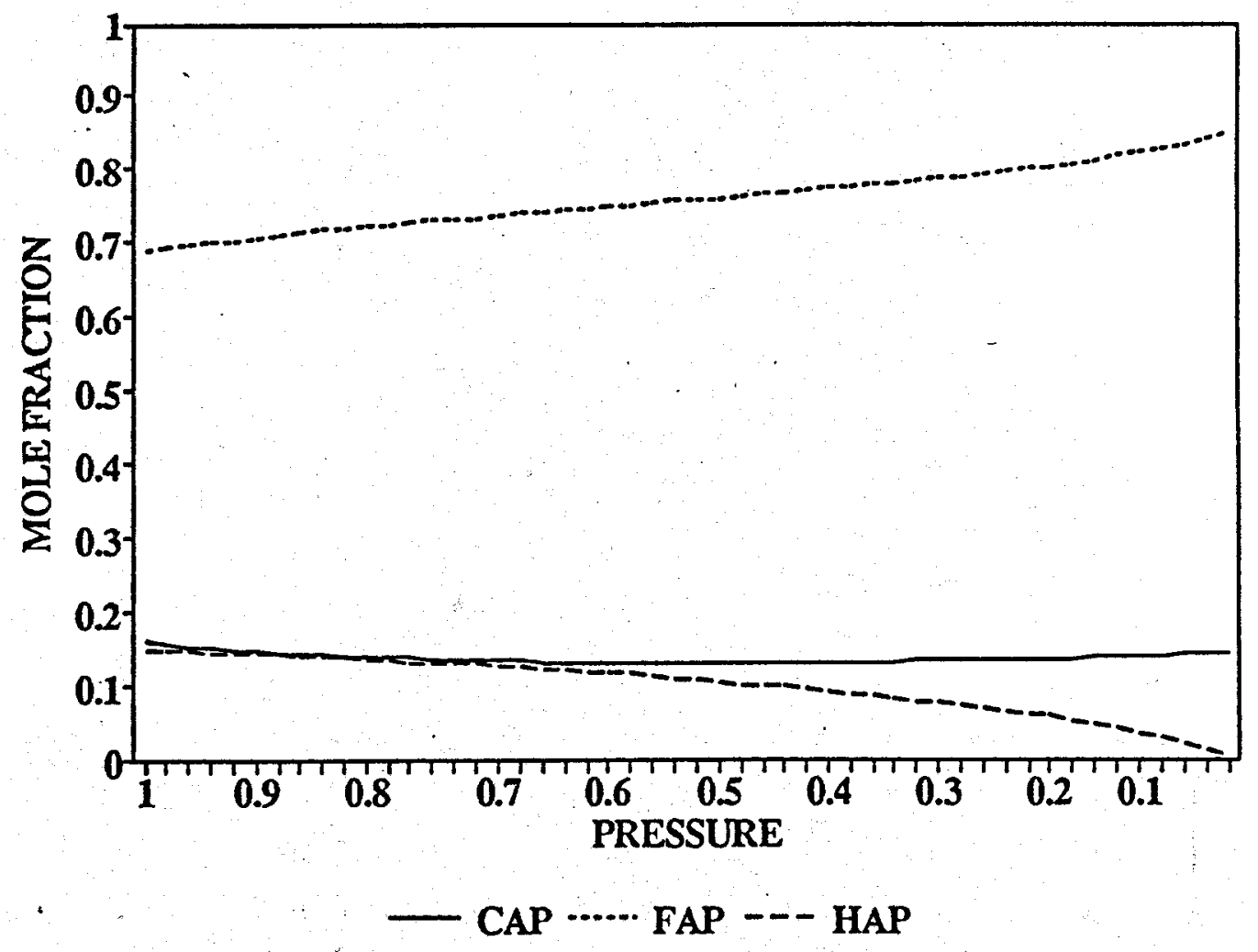

Ficueth 


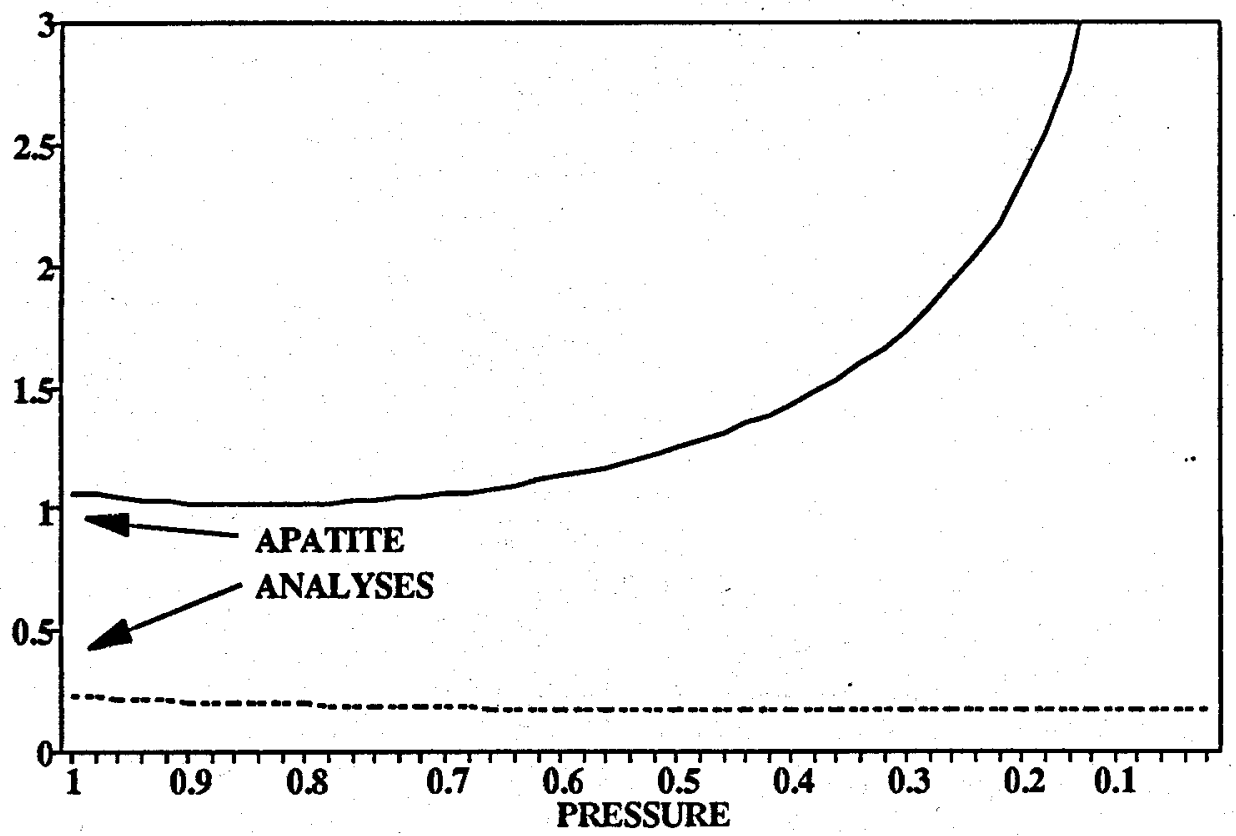

- X[CAP $y / X[H A P] \cdots \times$ [CAP $] / X[F A P]$ 

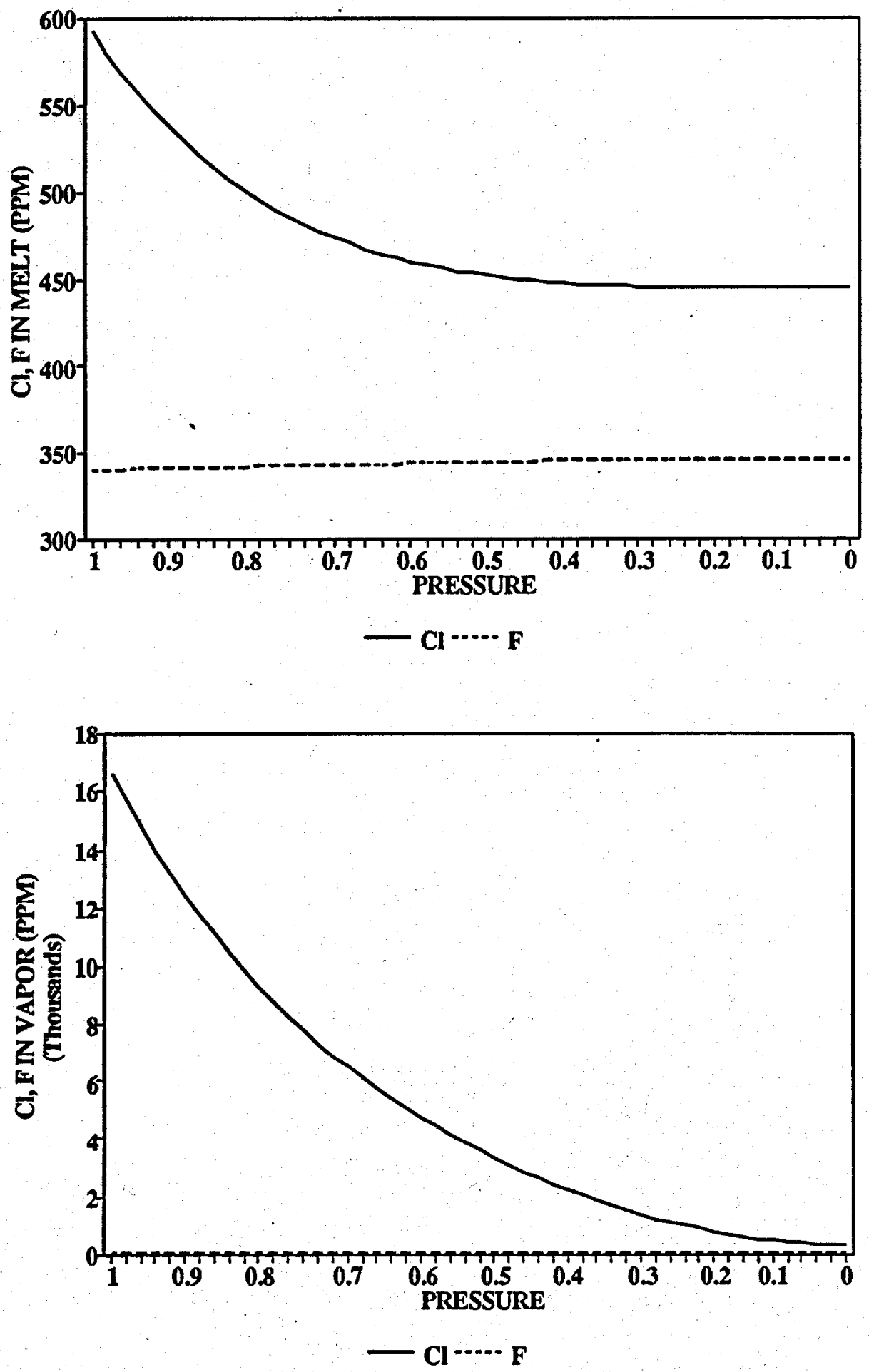